\title{
Real Estate Transactions Analyze, of the Theoretical and Practical Implementation Context
}

\author{
Msc Ledja Kingji \\ Law Faculty, University of Vlore, Albania \\ Prof Dr Alba Dumi \\ Economy Faculty, Mnagement Faculty, "Ismail Qemali" University of Vlore, Albania \\ Email: alba.besi12@gmail.com
}

Doi:10.5901/mjss.2016.v7n4p

\section{Abstract}

Property rights and ownership issues still unresolved which cause a large number of conflicts that, in some cases end up with a criminal offense. Disputes relating to ownership issues, listed in the first place. The right of ownership affects the overall economic development which affects the real estate market. Operation and administration of the right of ownership is associated directly with the market. The exact definition of property rights and registration of immovable property under the legislation affects the development of long-term projects related to urban planning and infrastructure development. This study aims to show that the real estate is an economic initiative for Albanian citizens or foreign legal entities, public or private. The purpose of this study is to reflect ways of acquiring ownership of real estate and legal protection that establishes the rule of law. The main goal is to build awareness of the institutions involved in the implementation of laws on real estate for more awareness in respect of the law, which includes a wide range of legislative ranging from law to gain ownership of the registration of the joy of ownership.

Keywords: Law analyze, real estate, legal protection, institutions, Albanian citizens

\section{Introduction}

Purpose of this paper research, is to analyze functionally elements of the legal and economic relations to real estate, through a more in depth review of specific operations, as a process of fulfillment of duties by the rule of law to legitimate owners of real estate.Functional structuring of economic legal relationship of real estate, in the context of theoretical and practical implementation. The rule of law should guarantee ownership and possession of property from the rightful owners bringing stability to the sector of real estate, reduce disputes to gain this right, facilitating transactions related to properties.

\subsection{The aim of this paper research}

The property reforms, like this: management, protection, comprise three main pillars in this paper.

1. Brief review of real estate legislation.

2. State agencies as ZRPP (office of real estate registration), AKKP (returns agency and compensation of property) and ALUIZNI (Agency for Legalization, Urbanization and Integration of Informal Areas I Constructions).

3. Cooperation between local and central government.

4. Property database.

\subsection{The procedure of registration of real estate.}

Institutional, technological changes, administration agencies, taking place in Albania. These are following parts like this:

a) The monitoring of implementation reforms.

b) Coordination of efforts to resolve the key issues of ownership.

By respecting these objectives the result is very clear: "A state based on strict adherence to the law, based on the 
principle of transparency, motivated to implement national and international strategies for Albania's integration into European structures."

The study was conducted as a theoretical and empirical treatment of the basic elements of economic and legal relationship to real estate. The methodology aims to realize direct contacts with representatives of the institutions involved in this field in order to create a true picture of the state of relations of ownership of immovable property.

The method used to collect survey data was our work experience and interviews with other officials in these key institutions as ZVRPP Vlora(office of real estate registration), ALUIZNI

Banks that deal with credit-granting, court, real estate agencies etc.. A semi was used interviews, the interview questionnaire was designed in open-ended questions and closed-ended questions. Closed-ended questions served us to provide general information on the registration of real estate and the market buying-selling real estate.

Supporting methods in this study were observing and keeping a diary for providing data where we registered daily experience of these institutions.

In what the report is the protection and guarantee of public property? Guarantee of private property and identify the constraints on its public interest. Consequently we support them, guaranteeing the other categories in the light of community property.

The Constitution of the Republic of Albania about how to create private property refers to specific laws. (Property acquired by gift, inheritance, purchase, or any other classical means provided in the Civil Code. Article 41/2). In the constitutional sense it is a guarantee of reinforcing respect the right of private property, leaving no chance to recreate that power absolute and transforming private property into collective guise of public interests, as happened in the former Communist part of which was also Albania.

\subsection{The purpose of the study}

The operation of the law in "Real Estate", as the law in action can only be understood if seen its legal environment, which is the legal framework of registration of land on the one hand, and law enforcement procedures on the other.

"Real Estate Law" or "Law of the Land", was developed in Europe as a mix of tribal-feudal law and Roman law on the other. While mortgages are rooted in both laws, in roman law and tribal law.Subnational strong differences exist in the UK, which consists of three different systems - England and Wales, Scotland and Northern Ireland - which coexist with each other. Subnational differences exist in Spain. The Constitution of the famous British unwritten constitutional law protects individual property and provides that expropriation can only be done in the public interest and against compensation for landowners.

Result I: Which are the conditions for the validity of legal action?

"Legal action is the legal expression of the will of the natural or legal person intends to create, alter or extinguish rights or civil liabilities." That a legal action must be available to meet these conditions:

1. Parties to perform legal action must have the capacity to act; The ability of the parties to act in a legal action requires the capacity to act of the parties because of the presumption that the will of a unable may not be accurate. Ability to act is the ability of the person with his actions acquires rights and assumes obligations. Ability to act implies the existence of eligibility and takes its full form when people reach the age of 18 . Ability to act is linked not only to the achievement of a certain age but also mental ability.

2. Will internal parties to a transaction must comply with its external appear. This expression of will is closely linked with the desire of the person to carry out legal action, which is aimed at the arrival of the consequences of certain birth modification or termination of civil rights or obligations. So natural or legal person displays his free will at the same time this will be legal.

Result II: Which would be considered the moment of acquisition of the property? The signing of the purchase contract by the parties before a notary, or that the property registration at the relevant registry of real estate?

The buyer or recipient of this asset becomes its rightful owner at the time of signing the contract at the notary gaining all the rights and obligations associated with the ownership right to.

Result III: Which is the effect of registration of the contract of alienation of immovable property in the register of real estate?

- What effect does the contract between the parties that have implemented legal action and what effect has the registration or non-registration of this contract in the relevant register of real estate for third parties?

- Does an invalid legal action being registered in the relevant register of title to real estate?

Not to be confused forms of contract to the effect of the legal validity of an ordinary formality as transcription / or registration of legal action in the real estate records.Transcription or registration is a necessary tool to give publicity 
contract to make known its existence and the owner of the third. Transcription has a declaratory release function. Contract as mutual legal action if it meets the conditions for its validity even if not registered in the register of real estate is completely valid between the parties that have done that.It is the contract between the parties that transferring ownership of real estate, creating real rights over the property and legitimizes owner to seek and protect these rights.

Result IV: Form of legal action?

In Article 659 of the Civil Code provided that "The contract is not nothing but a legal action through which one or more parties to create, alter or extinguish a legal relationship".

\section{Research Goal}

Albanian state after 1912 began to gradually replace the Turkish legislation on the ground, reaffirming the regime and legal regulation of the land and rights of its subjects legal, while respecting the legal regime under the right canonical acting more in northern Albania in some areas of the south.

Who arranged legally legislation on land relations began with the fundamental status of the years 1925-1928, which ended the division of the land under the 1856 Law and the lands were divided into state ownership, legal persons and physical persons.

Civil Code of Zog regime in 1929, the property was sacred and inviolable. Based on this principle with $\mathrm{He}$ appointed a law "On mortgage offices and their taxes" date 17.04 .1929 was abolished cadastral and mortgage offices were established.

To analyze the right of ownership is often back in the 1990s, changing the political system in affect national privatization process of state common property before ' 90 . It established a private property rights was reflected in the initial phase on houses, agricultural land, industrial land and buildings or services, as well as to return the properties claimed by their legal owners held before 1945.

Every person (natural or legal person) that owns legally an asset not only owns the land as physical effects of the economic - social relevant, but must own the property law on the ground, thus protecting legally entirety of the rights and obligations of the. This is the static of a legal system. While transactions or other actions in volume, space and time of these "legal title" make up "dynamic regulation" legal and legal development - actual relationships on earth.

Given the historical overview of the legal regime of the land in Albania, we see that there has been a poorly functioning or registration Cadastral institutions in various stages of development. We noticed that the land reforms, have not always served the interests of the citizens of this country. We had also the institution collapsing rural cadastre and mortgage diversity of privatization in the early actions of the transition period. On the basis of these problems we had need of conception model Land Market.

\section{Sample and Data Collections}

In the 1993 Census Act was passed, which institutionalized the system of registration. This law protects the rights of owners of real estate providing a reliable and strong ownership and other interests related to real estate. This system is simple and inexpensive to maintain and administer.

It provides the public the necessary information on buying and selling, mortgage and lease of property ensuring the basis for an economy to market-oriented and allows for the creation of a geographic information system (GIS), information assets as a part integral and essential.

Although this system is included in a registration procedural act independently, it contains legal definitions of the Civil Code for different forms of ownership, mortgages, leases and other legal rights over immovable property. From the observations that i made at the offices of registration of real estate and the contacts i have had there with the civilians of different i noticed that information on Real Estate held in the offices of the Registry is a reflection of what really exists.

Property records (cards) provide that information on ownership and other interests that do not need further verification. There is a guarantee that the information on file is correct and if someone harmed by inaccurate information to the ZRPP(office of real estate registration), can be compensated by the state. According to the opinions of people spending fees for Registration Offices are somewhat lower, despite his wealth or location and this creates incentives to enter the Registration System.

Law on Registration of Real Estate is designed to handle concepts basis of a parcel based registration system of property rights and at the same time to meet the needs of an administrative system of land, which can be successful in Albania. Each volume Recording holds a card for each parcel of PP (real estate), making the registrar responsible for keeping the Map Index Registration Registration for the PP ( real estate) surface in a Registration Office. 
Under the law limits indicated in the HTR (Registration Interactive Map) are indicative of the actual location of property boundaries and not any imaginary boundary. Under the law a limit is a closed surface which determines where an owner's property ends and where another begins wealth. If there is a dispute over borders and parties resolve the conflict itself, the registrar will register the agreement signed by both parties.

If the parties can not resolve the dispute Registrar will instruct them to take the matter to court. Initial registration of real estate and particularly stage 90-day public display in a visible place for public examination, within a cadastral area where the property is located, to the maximum avoids conflicts.

"First of all when it comes stability property and the peace of the community is very important to have a measure somehow wrong plot where the line actually exists, rather than having a measure extremely precise place where the line (border) it does not exist " (Muldford in 1912).From the information that we got in Imobiliare Agency Century21, we have illustrated the real estate as an investment. The rent-sale report exactly as they change requests and offers for real estate in recent years.

Before 4 years has been higher sales compared with 2014. This rates, implying in the process of buying and selling, because it causes increasing demand for (acquiring real estate for rent).

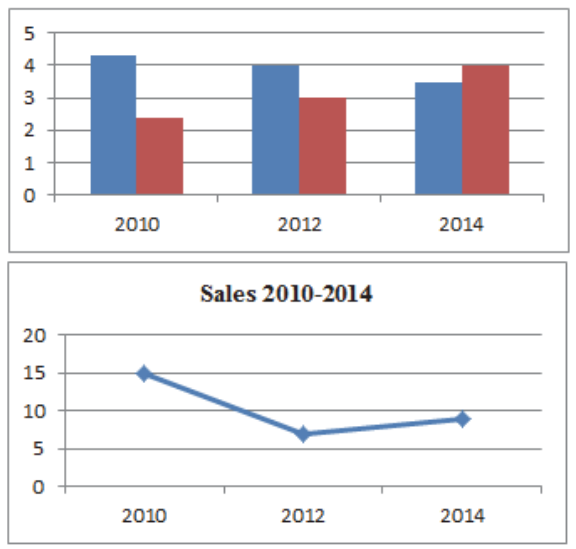

Demand for purchase of apartments has been very high in 2010 compared with recent years, the demand for the purchase of apartments has declined significantly in 2012. Requirements are higher for apartments $1+1$ compared with 2 + 1 apartments. Prices range from EUR 500-800euro. Requirements are more coastal zone compared to the center. Ratio $70 \%$ to $30 \%$.

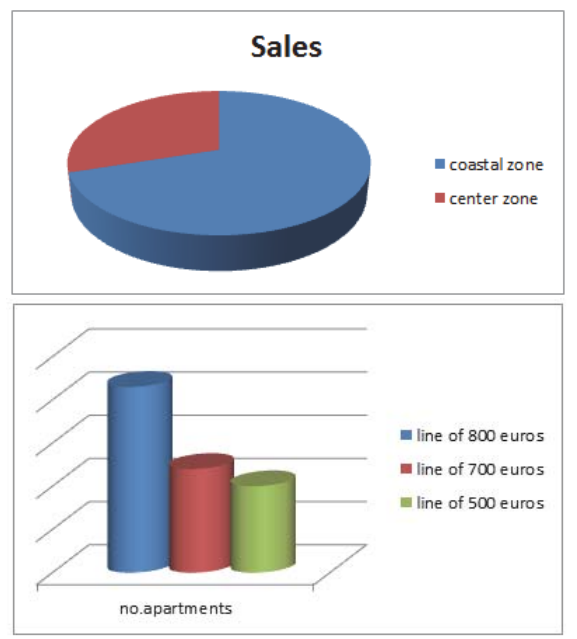


Rent: In the past 3 years rent has the highest demand in comparison with the requirements for the purchase of apartments, this for reasons of falling purchasing power.

Overall: Requirements for sales have dropped $20 \%$, as a consequence of this result, the agency has done a decrease in sales price by $20 \%$ (from 600Euro at EUR 500). More requirements for rent increase, the agency has a price discount up to $20 \%$.

\section{Recommendations}

Real estate agencies should use social networks for providing information. Sales agents of the register should collect as many details about the preferences of customers. The essential elements that make a difference between the groups purchasing are promotion, pricing, interiors and first impressions about the apartment, the distance from areas of daily activity, the presence of green areas and the distance from noise, safety, persons influencing functionality of the apartment and personal achievements.

Unification of the Property database should be based on legal ownership documents in accordance with cartographic data.So in the case of expropriation for purposes of legalization should find more appropriate means that the damage to be as low as possible for the owners. Making the property immediately, without an immediate or short-term compensation, fair and realistic solution is not proportional.

\section{Conclusions}

Property management process is a matter which relates directly to the overall development of the country.

The property rights helps in the design and improvement of urban planning as well as infrastructure development.The rule of law must guarantee the security of legal ownership of the property serving as follows: development of real estate sector; reducing disputes and facilitating property transactions. Real Estate transactions are very diverse. Constitutional principle of freedom of contract is the rule in all European countries, but property transactions are significantly affected by:

1- Consumer protection instruments;

2- The limitations of public law for certain transactions;

3- Fees;

4- Subsidies granted to build houses.

Albanian Constitutional Court specifically stated: -"In our day, the constitutional theory provides such a definition of the concept of" expropriation ", according to which a subject can be deprived of property rights that in favor of another entity public generally, but not necessarily". So it recognizes the expropriation in favor of private persons made on the basis of a policy calculated to achieve social justice within the community.

\section{References}

Law No. 7501 July 19, 1991, "For the Land"

Law no. 7652 of December 23, 1992, "For privatization of state housing"

Law no. 7698 April 15, 1993, "For Property Restitution and Compensation of Former Owners"

1995 Law No. 7843 July 13, 1994, "For the System of Registration of Real Estate".

Law No. 7850 dated 29.07.1994 "Civil Code of the Republic of Albania", the Official Journal of the Republic of Albania No. 11, October Constitution; 1994 edition of the National Assembly

2004 Law No. 9404 of October 29, 2004, " Legalization and Urban Planning of Informal Areas";

2004 Law No. 9235 of July 29, 2004, "For Property Restitution and Compensation";

2006 the Law no. 9482 of 3 April 2006, "Legalization, Urbanization and Integration of Illegal Constructions"

The 2007 Law No. 9780 of July 16, 2007, "Building Inspection";

The 2009 Law No.10119 of April 23, 2009, "For Territorial Planning";

The 2012 Law No. 33/2012 "For the Registration of Real Estate";

The 2012 Law No. 55/2012 "For some amendments to the Law No: 9235 dated 29.7.2004 Restitution and Compensation of Property, as amended";

Baum, A., "Commertial Real Estate Investment", Estates gazette, 2002.

ALIU Elfrida, "Fundamentals of real estate valuation"

Isaak, D., "Property investment", Palgrave, 2002.

Parnham, P., Rispin C., "Residential property appraisal", Spon Press, 2001. 
Zrobek, S., "Market Value and cost value-similarities and differencies", Selected aspects of Cost Approach in property valuation, Scientific Monograph, fq. 10-16, OLSZTYN, 2011.

Britton, W., Connellan, O. P., Crofts, M. K, "The Cost Approach to Valuation", RICS and Kingston Polytechnic, 1991.

Millington, A.F., "An introduction to property valuation", Fifth edition, Estates Gazette, 2000.

"European Valuation Standards", Seventh Edition, TEGoVA, 2012.

International Valuation Standards Committee, August 2007, "IVC 2007", 8th Edition. International Valuation Standards Committee.London .UK.

Sirota, D., "Essentials of Real Estate Investment", 7th edition, Dearborn Real Estate, 2004.

"Albania Progress Report", European Commission Staff Working Report, October 2012

Doing Business 2013, World Bank Report 2013

"Land policies for growth and poverty reduction": Key issues and challenges ahead", OECD; Paper, Klaus Deininger (2005)

"BEEPS At-A-Glance 2008" Albania report, The World Bank Group, January 2010

"Governance in the Protection of Immovable Property Rights in Albania": A Continuing

Challenge", World Bank Report No:62519-AL , June 2011

"Land Administration in the UNECE Region. Development trends and main principles", United Nations Economic Commission for Europe Guidelines (2005)

Stanley and Adlington (2007) "world Bank Experience in Land Administration in the Transition Economies of Eastern Europe and Central Asia"

"Cross-Cutting Strategy The reform of property rights 2012 - 2020", the Ministry of Justice, Republic of Albania, 2012

Schargrodsky and Galiani (2006) "Property Rights for the Poor: Effects of Land Titling" 